\title{
Coping and adaptation of adults with cancer: the art of nursing care*
}

* Article financed by the bank of projects for fostering research and technological development and innovation, in the funding modality No. PSEM01-2019.

Lina Marcela Cepeda-Trujillo

https://orcid.org/0000-0002-4136-5781 Universidad Surcolombiana, Neiva, Colombia. u20161147749@usco.edu.co

Jesús Miguel Mosquera-Aguirre

https://orcid.org/o0oo-0001-9238-8978 Universidad Surcolombiana, Neiva, Colombia. u20161146418@usco.edu.co

Daniela Yurani Rojas-Atehortua

https://orcid.org/0000-0002-5824-752X Universidad Surcolombiana, Neiva, Colombia. u20161145396@usco.edu.co

Alix Yaneth Perdomo-Romero https://orcid.org/0000-0003-1390-9718 Universidad Surcolombiana, Neiva, Colombia. alixyaneth.perdomo@usco.edu.co

Received: 16/10/2020

Sent to peers: $17 / 11 / 2020$ Approved by peers: 08/06/2021

Accepted: 27/09/2021
DOI: 10.5294/aqui.2022.22.1.7

Para citar este artículo / To reference this article / Para citar este artigo

Cepeda-Trujillo LM, Mosquera-Aguirre JM, Rojas-Atehortua DY, Perdomo-Romero AY. Coping and adaptation of adults with cancer: the art of nursing care. Aquichan. 2022;22(1):e2217. DOI: https://doi.org/10.5294/aqui.2022.22.1.7 
Subject: Chronic care.

Contribution to the subject: Applying a nursing theory enables a better understanding of the human experiences that are lived in the process of coping and adaptation to cancer, identifying which strategies favor and undermine the new situation that patients are going through. It is a priority for nursing as a whole to strengthen coping and adaptation, through knowledge that guides a comprehensive approach and quality care to patients. 


\begin{abstract}
Objective: To determine the coping and adaptive capabilities in patients with cancer undergoing treatment. Methodology: This was a quantitative and descriptive cross-sectional study; the sample consisted of 100 patients with a cancer diagnosis who received chemotherapy and/or radiotherapy treatment between June and August 2019, meeting the inclusion criteria. The Coping and Adaptation Processing Scale (CAPS) was used. Results: $53 \%$ of the patients participating in the study presented high coping and adaptive capabilities; $40 \%$ presented medium capabilities, and $7 \%$ presented low capabilities. Conclusion: Continuous follow-up is extremely important throughout the disease process; having a romantic partner becomes a protective factor since patients feel heard and cared for, which motivates them to follow through with the treatment. In the nursing field, knowing the experience of those who live with an illness allows for transcending and impacting care by providing holistic attention to patients.
\end{abstract}

\title{
Keywords (SOURCE: MeSH, DeCS)
}

Nursing; caregivers; cancer; neoplasms; chemotherapy; radiotherapy. 


\section{Afrontamiento y adaptación del adulto con cáncer: el arte del cuidado de enfermería*}

*Artículo financiado por el banco de proyectos de semilleros de investigación y desarrollo tecnológico e innovación, en la modalidad de financiación No. PSEM01-2019.

\section{Resumen}

Objetivo: Determinar la capacidad de afrontamiento y adaptación en personas con cáncer en tratamiento. Metodología: estudio cuantitativo y descriptivo de corte transversal; la muestra fue conformada por 100 pacientes con diagnóstico de cáncer que asistieron a tratamiento de quimioterapia y/o radioterapia entre junio y agosto del 2019, cumpliendo los criterios de inclusión. Se utilizó la Escala de Medición del Proceso de Afrontamiento y Adaptación (ESCAPS). Resultados: $53 \%$ de los pacientes estudiados poseen una capacidad de afrontamiento y adaptación alta; $40 \%$ obtuvo capacidad media y $7 \%$ una capacidad baja. Conclusión: el acompañamiento continuo es de gran importancia en todo el proceso de la enfermedad; tener una pareja sentimental se convierte en un factor protector pues los pacientes se sienten escuchados y atendidos, lo cual los motiva a continuar con el tratamiento. En el área de enfermería, conocer la experiencia de quienes viven una enfermedad permite trascender e impactar el cuidado brindando una atención holística.

Palabras clave (Fuente: MeSH, DeCS)

Enfermería; cuidadores; cáncer; neoplasias; quimioterapia; radioterapia. 


\section{Enfrentamento e adaptação do adulto com câncer: a arte do cuidado de enfermagem*}

* Artículo financiado por el banco de proyectos de semilleros de investigación y desarrollo tecnológico e innovación, en la modalidad de financiación No. PSEM01-2019.

\section{Resumo}

Objetivo: determinar a capacidade de enfrentamento e adaptação em pessoas com câncer em tratamento. Materiais e método: estudo quantitativo e descritivo, de corte transversal; a amostra foi conformada de 100 pacientes com diagnóstico de câncer que passaram por tratamento de quimioterapia e/ou radioterapia entre junho e agosto de 2019, cumprindo com os critérios de inclusão. Foi utilizada a Escala de Medição do Processo de Enfrentamento e Adaptação. Resultados: $53 \%$ dos pacientes estudados apresentaram capacidade de enfrentamento e adaptação alta; $40 \%$ obtiveram capacidade média e $7 \%$, capacidade baixa. Conclusões: o acompanhamento contínuo é de grande importância em todo o processo da doença; ter um parceiro(a) sentimental se torna um fator protetor, pois os pacientes se sentem escutados e atendidos, o que os motiva a continuar com o tratamento. $\mathrm{Na}$ área de enfermagem, conhecer a experiência de quem vive uma doença permite transcender e impactar o cuidado, oferecendo uma atenção holística.

Palavras-Chave (Fonte: MeSH, DeCS)

Enfermagem; cuidadores; câncer; neoplasias; quimioterapia; radioterapia. 
Cancer is a disease that causes more than eight million deaths each year worldwide (1) and causes the largest number of premature deaths (2). In America, it is the second leading cause of death; during 2018, 3.8 million cases were diagnosed, and 1.4 million people aged 69 years or under died from cancer (3).

The diagnosis of cancer has a significant impact on biological, psychological, physical, and social aspects. It involves multiple challenges and, therefore, the experience of having cancer is highly distressing since it forces individuals to deal with affliction, deterioration, death, transcendence, concepts for each of which they must seek a personal meaning. It is at that moment where coping becomes the main intermediary mechanism in the presence of crisis or in difficult situations involving stress; it is recognized that the behaviors used as coping strategies can promote adaptation (4).

Callista Roy defines coping capability as the innate or acquired ability to generate a response, using new strategies to adapt effectively to challenging changes (5). Cancer leads patients to face various changes in their lives which generate negative feelings and emotions in those who suffer from it and in their families; likewise, if effective coping strategies are used, the psychosocial effects produced by this disease can be mitigated (6). The nursing field needs to know how to promote health for its patients, but also how to help them cope with the changing episodes and challenges posed by their disease (7).

Consequently, the present research aims to determine the coping and adaptive capabilities of patients undergoing cancer treatment.

\section{Methodology}

This was a quantitative and descriptive cross-sectional study whose population consisted of users who received chemotherapy and/or radiotherapy treatment between June and August 2019 in a cancer unit. A total of 100 users with a diagnosis of cancer participated, who were chosen non-probabilistically and by convenience, and who met the following selection criteria: i) being over 18 years of age, ii) having a diagnosis of cancer recorded in the clinical history for more than three months, iii) undergoing active chemotherapy and/or radiotherapy treatment, and iv) expressing their voluntary acceptance to participate by signing the informed consent form.

The study was submitted to the hospital's ethics committee, in accordance with Resolution 8430 of 1993, as well as Laws 911 of 2004 and 1581 of 2012, Decree 1377 of 2013, the Declaration of Helsinki, and the ethical principles of confidentiality, beneficence, nonmaleficence, and autonomy.

Sociodemographic variables included age, gender, marital status, socioeconomic stratum, educational level, occupation, income, number 
of people in the household, number of dependents, main support person, place of origin, place, and area of residence, and difficulty of mobility. The clinical variables were the type of cancer, stage, time of diagnosis, type, and duration of treatment, the latter collected from the patients' medical history.

Additionally, the Coping and Adaptation Processing Scale (CAPS) was used, which is suitable for measuring coping processes, designed by Callista Roy in 2004; this instrument consists of 47 items that, by using short statements, describe the way individuals respond to a crisis or a difficult event and is scored on a Likert scale (8). The instrument was translated into Spanish, with apparent face validity, reliability between 0.90 and 0.94 , and stability of 0.8 (9). It was subsequently validated by Paola Sarmiento, Johana Botero, and Gloria Carvajal, who provided continuity to the construct validity and generated a final version of the CAPS scale composed of 33 items, with a Cronbach alpha of 0.71 , face validity of $95 \%$, and content validity of 0.83 . The response options range from o (never) to 3 (always), with a minimum score of $\mathrm{o}$ and a maximum of 99 points; the level of coping and adaptation will be considered low (from o to 56 points), medium (from 57 to 70 points) and high (from 71 to 99 points) (10).

The researchers collected the information by applying and filling out the instrument manually and then transferring it to a Google ${ }^{\circledR}$ form which generated a database in the Excel ${ }^{\circledR} 2019$ program where the data were tabulated, coded, and exported to the Stata ${ }^{\circledR} 2015$ version 14.0 program.

Absolute and relative frequencies were used to describe the quantitative variables of the study. The normality of the continuous variables was determined with the Shapiro Wilk test, using the mean or median in the corresponding case; subsequently, the association between the sociodemographic/clinical variables and the Coping and Adaptation Scale was established using the Chi-squared test and considering a statistical significance of $p<0.05$.

\section{Results}

Most participants were female ( $75 \%)$, in the adult age range (61 \%), with a median age of 54 years, a minimum age of 21 years, and a maximum age of 81 years, from a low socioeconomic standing (89 \%) and receiving support from their partner (50\%) and their children (28\%) (Table 1).

Most of them live in urban areas $(78 \%)$, some of them live with two people in their household ( $42 \%)$, some have a dependent (33\%), and some stated that they face financial difficulties in commuting to the healthcare institution ( $42 \%$ ).

The participants have been diagnosed primarily with breast cancer ( $43 \%$ ), as well as gynecologic (17\%), hematologic (11\%), and gastrointestinal (10\%) cancers (Table 2 ). 
8 Table 1. Sociodemographic characterization of cancer patients, $n=100$

\begin{tabular}{|c|c|c|}
\hline Variable & $\mathbf{n}$ & $\%$ \\
\hline \multicolumn{3}{|c|}{ Age } \\
\hline $18-28$ years & 3 & 3 \\
\hline 29-59 years & 61 & 61 \\
\hline 60 years or older & 36 & 36 \\
\hline \multicolumn{3}{|c|}{ Sex } \\
\hline Male & 25 & 25 \\
\hline Female & 75 & 75 \\
\hline \multicolumn{3}{|c|}{ Marital status } \\
\hline Married & 48 & 48 \\
\hline Free union & 15 & 15 \\
\hline Widow/Widower & 6 & 6 \\
\hline Divorced or separated & 3 & 3 \\
\hline Single & 28 & 28 \\
\hline \multicolumn{3}{|c|}{ Socioeconomic stratum } \\
\hline Low & 89 & 89 \\
\hline Medium & 11 & 11 \\
\hline \multicolumn{3}{|c|}{ Level of education } \\
\hline Primary & 41 & 41 \\
\hline Bachelor's Degree & 30 & 30 \\
\hline Technician/technologist & 16 & 16 \\
\hline Undergraduate & 10 & 10 \\
\hline Postgraduate & 3 & 3 \\
\hline \multicolumn{3}{|c|}{ Occupation } \\
\hline Housekeeper & 45 & 45 \\
\hline Farmer & 4 & 4 \\
\hline Unemployed & 13 & 13 \\
\hline Employed & 12 & 12 \\
\hline Freelancer & 14 & 14 \\
\hline Retired & 12 & 12 \\
\hline \multicolumn{3}{|c|}{ Primary supporting person } \\
\hline Partner & 50 & 50 \\
\hline Son/daughter & 28 & 28 \\
\hline Parents & 15 & 15 \\
\hline Sibling & 3 & 3 \\
\hline Cousin & 1 & 1 \\
\hline Nobody & 3 & 3 \\
\hline
\end{tabular}


Table 2. Clinical characterization of cancer patients, $n=100$

\begin{tabular}{|c|c|c|}
\hline Variable & $\mathbf{n}$ & $\%$ \\
\hline \multicolumn{3}{|l|}{ Type of cancer } \\
\hline Breast & 43 & 43 \\
\hline Gynecologic (cervix, endometrium and ovary) & 17 & 17 \\
\hline $\begin{array}{l}\text { Hematologic (acute lymphoblastic leukemia, non-Hodgkin's lymphoma, Hodgkin's } \\
\text { lymphoma, and multiple myeloma). }\end{array}$ & 11 & 11 \\
\hline Gastrointestinal (gastric, ampulla of Vater, colon and rectum) & 10 & 10 \\
\hline Head and neck (nasal cavity, thyroid, pharynx, oropharynx, and parotid gland) & 7 & 7 \\
\hline Prostate & 5 & 5 \\
\hline Soft tissue (mesenchymal angiosarcoma, leiomyosarcoma, abdominal wall) & 3 & 3 \\
\hline Lung & 2 & 2 \\
\hline Skin & 2 & 2 \\
\hline \multicolumn{3}{|l|}{ Stage of cancer } \\
\hline 1 & 8 & 8 \\
\hline II & 25 & 25 \\
\hline III & 38 & 38 \\
\hline IV & 18 & 18 \\
\hline NA & 11 & 11 \\
\hline \multicolumn{3}{|l|}{ Type of treatment } \\
\hline Chemotherapy & 58 & 58 \\
\hline Radiotherapy & 33 & 33 \\
\hline Chemotherapy and radiotherapy & 9 & 9 \\
\hline
\end{tabular}

Source: Own elaboration.

Participants demonstrated to have the following capabilities: high coping and adaptive capabilities (53\%), medium (40\%), and low (7\%) capabilities. Participants felt comfortable handling the situation in the best possible way ( $84 \%$ ) and seek all means available to cope with the situation ( $75 \%$ ); likewise, they accepted the situation as it presented itself ( $72 \%)$, had expectations of how it would be resolved $(67 \%)$, were attentive to any related issue $(65 \%)$, took the necessary time before acting ( $65 \%)$, clarified any doubts (64\%), never gave up easily (68\%), felt they could handle the situation (55\%), adopted new skills to resolve it ( $50 \%$ ), never felt guilty, never overreacted, and never became stuck and confused ( $49 \%)$. While they focused their feelings and emotions in a helpful way (44\%), they had difficulties in completing activities, tasks, and projects (37\%), never thought about the problem (33\%), and made drastic changes in their lives $(28 \%)$.

Regarding the associations between coping capabilities with the different variables, two were found to be statistically significant. The first identified that participants who had a partner presented high coping and adaptive capabilities ( $55 \%$ ), which is evidenced by a $p=0.020$ (Table 3 ). 
10 Table 3. The association of the coping and adaptation level according to the primary support person, $n=100$

\begin{tabular}{|c|c|c|c|c|c|c|c|}
\hline \multirow{2}{*}{ Variable } & \multicolumn{2}{|c|}{ Low coping } & \multicolumn{2}{|c|}{ Medium coping } & \multicolumn{2}{|c|}{ High coping } & \multirow{2}{*}{$\mathbf{p}$} \\
\hline & $\mathbf{n}$ & $\%$ & $\mathbf{n}$ & $\%$ & $\mathbf{N}$ & $\%$ & \\
\hline Parents & o & 0 & 9 & 23 & 6 & 11 & \multirow{6}{*}{0,020} \\
\hline Sibling & 1 & 14 & 1 & 3 & 1 & 2 & \\
\hline Partner & 3 & 43 & 18 & 45 & 29 & 55 & \\
\hline Son/daughter & 2 & 29 & 10 & 25 & 16 & 30 & \\
\hline Cousin & 1 & 14 & 0 & 0 & 0 & 0 & \\
\hline Nobody & o & 0 & 2 & 5 & 1 & 2 & \\
\hline
\end{tabular}

Source: Own elaboration.

The second association demonstrated that patients with high coping capabilities were undergoing chemotherapy (68\%), and those with low coping capabilities were undergoing radiotherapy treatment $(71 \%)(p=0.005)$ (Table 4).

Table 4. The association between the coping and adaptation levels according to the type of treatment, $n=100$

\begin{tabular}{|c|c|c|c|c|c|c|c|}
\hline \multirow{2}{*}{ Variable } & \multicolumn{2}{|c|}{ Low coping } & \multicolumn{2}{|c|}{ Medium coping } & \multicolumn{2}{|c|}{ High coping } & \multirow{2}{*}{$\mathbf{p}$} \\
\hline & $\mathbf{n}$ & $\%$ & $\mathbf{n}$ & $\%$ & $\mathbf{n}$ & $\%$ & \\
\hline Chemotherapy & 2 & 29 & 20 & 50 & 36 & 68 & \multirow{3}{*}{0,005} \\
\hline Radiotherapy & 5 & 71 & 12 & 30 & 16 & 30 & \\
\hline Chemotherapy and radiotherapy & o & 0 & 8 & 20 & 1 & 2 & \\
\hline
\end{tabular}

Source: Own elaboration.

\section{Discussion}

Breast cancer was the most prevalent (11), followed by cervical and endometrial cancer, which accounted for the greater participation of the female gender in this study; regarding the male gender, the types of cancer with the greatest presentation were prostate and head and neck cancers. In both sexes, stages II and III were prevalent, while the effects of treatment were significantly more common in adults who received radiotherapy (12).

Women with breast cancer applied active coping strategies, which is expressed through positive reframing, acceptance, and the use of emotional support (13), strategies that are similar to others also used, such as expecting a solution, accepting reality, and the presence of support, without these strategies being influenced by the type of cancer. 
In addition, high expectancy and difficulty in completing activities were presented; this phenomenon has been described in a study in which, even in treatment, they esteem themselves and feel useful in society which demonstrates, with positive coping, high levels of hope (14). With a positive approach and orientation, it has also been demonstrated that such patients accept the diagnosis and adopt an optimistic posture (15). However, they may sometimes feel weak in performing daily life activities, become disinterested, fearful, and worried that they will get worse (16).

One of the coping strategies most commonly employed by oncology patients is emotional orientation, while the least used is avoidance (17). These are feelings that resemble feeling good when dealing with the situation as best as possible, never giving up easily, taking charge quickly, and accepting the disease without avoiding it. Other coping strategies that have been applied are the following ones: religiosity, positive re-assessment, problem-solving, and seeking professional support, which are similar to accepting the event, clarifying doubts, and seeking all possible means for its solution. Therefore, some report that the more these types of strategies are used, the lower the levels of anxiety and depression experienced by oncologic patients (18).

Additionally, they deploy strategies such as accepting their diagnosis, participating in different activities, seeking information, and expressing their emotions (19), which are related to those handled by the participants in this study in the search for all possible means to cope with the situation, viewing difficult situations as an opportunity or a challenge, proposing different solutions to resolve it and trying to clarify any doubts before acting, all of which contribute to improving the level of coping.

It is worth noting that no statistically significant difference was found between men and women in the use of coping strategies (20). Those who retain high coping and adaptive capabilities are mostly adults aged over 65 who use strategies such as a favorable and positive approach to decision-making (21), which does not correspond to this study's results, since no association with age was found.

It has been demonstrated that a relationship exists between strong family support and effective coping strategies (22); in effect, patients' families promote an adequate adaptation and their partners are identified as the most significant source of support in order to be able to talk openly on the topic. Even the support received is considered by some authors as the most important variable to value (23); thus, a stable partner is associated with support and daily care activities that influence especially the elderly (24). This is reflected in cases where the primary support person belongs to a consanguineous line and where those with high coping capabilities rely on their intimate partners for support.

It is relevant to mention the importance of assertive communication between the nursing staff and the companions, regarding 
which patients recognize their effectiveness - whether in the waiting room or virtually-, which allows them to be involved in the entire disease process in order to be able to identify discomfort and intervene promptly.

Meanwhile, other studies have found several restrictions in daily activities generated by cancer treatments $(25,26)$, which were especially evident in participants undergoing radiotherapy, who developed a low coping capability; one of the reasons for this lies in the lack of information provided by healthcare personnel regarding the treatment, the most important care needed by patients, or the changes that occur at the physical level (27).

The length of time from diagnosis was not associated with coping capabilities, but those who used strategies such as expressing positive emotions, reframing the experience positively, and cultivating a sense of peace and meaning in their lives reported greater stability during their diagnosis (28).

Furthermore, Acinas (29) observed that by delaying coping and not taking charge, the probability of feeling guilty and increasing distress increases; in this regard, the results of this research indicate that most participants have never felt guilty and have always taken charge of the problem quickly. Likewise, it has been reported that one of the most commonly used strategies is to implement radical changes six months after diagnosis (30), similar to what was found in our study in which some cancer patients made drastic changes in order to overcome the situation.

Similarly, it was evident that in the initial phase of treatment patients apply coping strategies focused on the event and the pursuit of religious practices or unrealistic thoughts (31), which did not demonstrate any dependence between the duration of treatment and the strategies used.

The responsibility of being in charge did not demonstrate any relationship with coping capabilities; however, if the patient is a direct caregiver, some degree of anxiety, stress, or extra burden may be generated, which limits the effective fulfillment of tasks related to the patient's occupation and treatment, and also affects the patient's level of adaptation (32).

Despite not evidencing concordance between occupation and coping in this study, a small group of housekeepers with breast cancer in Indonesia were found to be more likely to apply problem-focused coping strategies by positively re-assessing themselves and seeking social support, thus lessening the burden of their illness; on the other hand, those who demonstrated low levels of coping were those who used emotional strategies, that is, they distanced themselves and avoided their situation (33).

In addition to the physical and emotional impacts, patients with cancer must face challenges and threats related to the loss of finan- 
cial security and the lifestyle changes they must make; although no relationship was found between their income and their level of coping capabilities, interventions should be implemented to support their financial management during their illness (34).

The presence or absence of physical and/or economic difficulties was not relevant regarding coping levels; however, any barrier whether of physical, social, psychological or spiritual origin- has the potential to generate suffering when it is perceived as a threat and will not allow patients to cope and adapt (35).

Other variables that were not associated with the results of the coping levels in this study were the place of origin and residence, factors that have been considered as barriers in the literature, given that not only were the sociodemographic aspects, distance, or lack of regional services the factors identified as obstacles, but also cultural factors, communication, coordination and the limitation of means for diagnosis, all of which were considered disadvantages for oncologic patients (36).

Performing a timely nursing diagnosis in the care process allows for the implementation of interventions aimed at eliminating, increasing, decreasing, or altering the stimuli that threaten the objective of adaptation, where the most important aspect is for patients to never lose their resilience and to become stronger along with their support network.

Finally, cancer involves a process that is characterized by a series of stages that, as the disease and treatment progress, changes will be carried out in order to assist patients in adapting to the new situation. Healthcare personnel, and especially the nursing team that interacts with patients in a close and prolonged manner, must act responsibly and competently in a process that is becoming increasingly complex, due to new treatments, medications, and side effects; in fact, not having such assertiveness would trigger discomfort, frustration, or feelings of incompetence in healthcare providers and in their patients (37).

\section{Conclusions}

Permanent support is essential for patients with cancer, who demonstrate improvements by having partners and by allowing them to be accompanied during treatment sessions, which strengthens their adaptation to their new process.

Although the participants in this study presented high levels of adaptation, it is essential for healthcare providers - especially nursing personnel - to be aware of the processes that each patient goes through in order to cope with and adapt to a new situation such as the emergence of cancer; therefore, when talking to patients, it is necessary to inquire about stressful events in order to guide them towards stress reduction by promoting the active search for solu- 
tions, satisfaction with their actions and acceptance of the current situation, which allows patients to develop coping and adaptation capabilities regarding the process they are undergoing. Therefore, care is transcendent, leaving aside the intervention focused on pathology to focus on providing holistic, constant, humane, and professional care.

In light of the above, the nursing field, being aware of the impact that the diagnosis of cancer has on individuals, which is viewed by them as a life-threatening event, should lead a multidisciplinary management support network, in which the providers identify the adaptation needs according to the effects that occur at the physiological level, self-concept, interdependence, and the performance of their role. By performing a behavioral analysis and the internal and external stimuli that influence patients' health, a timely, continuous, and comprehensive management can be achieved, which subsequently allows sharing the benefits of the process with other patients.

\section{Acknowledgments}

To the Universidad Surcolombiana for its initiative and support in the research; to the Hospital Universitario for providing access, and to each one of the participants who freely decided to participate in this research.

Conflict of interest: None declared.

\section{References}

1. Cuenta de Alto Costo [Internet]. 2020: Día mundial contra el cáncer 2020. Colombia; 2020 febrero 4 [citado 2021 octubre 31]. Disponible en: https://cuentadealtocosto.org/site/cancer/ dia-mundial-contra-el-cancer-2020/

2. World Health Organization [WHO]. World health statistics 2019: Monitoring health for the sustainable develoment goals [Internet]. Geneva: WHO; 2019 [citado 2020 mayo 18]. Disponible en: https://apps.who.int/iris/bitstream/handle/10665/324835/97892 41565707-eng.pdf?ua=1

3. Organización Panamericana de la Salud [OPS] - Organización Mundial de la Salud [OMS]. La OMS describe los pasos para salvar 7 millones de vidas amenazadas por el cáncer [Internet]. 2020 febrero 4 [citado 2020 mayo 20]; notas de prensa. Disponible en: https://www.paho.org/es/noticias/4-2-2020oms-describe-pasos-para-salvar-7-millones-vidas-amenazadas-por-cancer

4. Song CE, Kim HY, So HS, Kim HK. Reliability and Validity of the Korean Version of the Coping and Adaptation Processing ScaleShort-Form in Cancer Patients. J Korean Acad Nurs [Internet]. 2018 [citado 2020 junio 7];48(3):375-388. DOI: https://doi. org/10.4040/jkan.2018.48.3.375

5. Roy C. Generating midle range theory: From evidence to practice. New York: Springer; 2013 [citado 2020 junio 7]. Disponible en: https://www.springerpub.com/generating-middle-range-theory-9780826110091.html\#description

6. Roy C, Bakan G, Li Z, Nguyen TH. Coping measurement: Creating short form of Coping and Adaptation Processing Scale using item response theory and patients dealing with chronic and acute health conditions. Appl Nurs Res [Internet]. 2016 [citado 2020 junio 7];32:73-79. DOI: https://doi.org/10.1016/j. apnr.2016.06.002

7. Dempster M, Howell D, McCorry NK. Illness perceptions and coping in physical health conditions: A meta-analysis. J Psychosom Res [Internet]. 2015 [citado 2020 junio 7];79(6):506-513. DOI: https://doi.org/10.1016/j.jpsychores.2015.10.006

8. Muder A, Vivien D. The Validation of the Coping and Adaptation Processing Scale Based on the Roy Adaptation Model. J Nurs Measurement [Internet]. 2014 [citado 2020 junio 7];22(3):368380. DOI: https://doi.org/10.1891/1061-3749.22.3.368

9. Gutiérrez C, Veloza MM, Moreno ME, Durán MM, López C, Crespo O. Validez y confiabilidad de la versión en español del instrumento "Escala de medición del proceso de afrontamiento y adaptación "de Callista Roy. Aquichan [Internet]. 2007[citado 2020 junio 7];7(1): 54-63. Disponible en: https://www.redalyc. org/articulo.oa?id=74170105

10. Sarmiento GP, Botero GJ, Carvajal CG. Validez de constructo de la Escala de Medición del Proceso de Afrontamiento y Adaptación de Roy, versión modificada en español. Index Enferm [Internet]. 2013 [citado 2020 Mayo 16]; 22(4):233-236. DOI: https:// doi.org/10.4321/S1132-12962013000300009

11. International Agency for Research on Cancer - WHO. Estimated age-standardized incidence rates (World) in 2020, worldwide, both sexes, all ages [Internet]. Cancer Today; 2020 [citado 2020 junio 8]. Disponible en: https://gco.iarc.fr/today/ 
online-analysis-multi-bars? $v=2020 \&$ mode $=$ cancer\&mode_population $=$ countries $\&$ population $=900 \&$ populations $=900 \& k e y=a s-$ $r \&$ sex $=0 \&$ cancer $=39$ \&type $=0 \&$ statistic $=5$ \&prevalence $=0 \&$ pop ulation_group $=0 \&$ ages_group []$=0 \&$ ages_group []$=17 \&$ nb_ items $=10 \&$ group_cancer $=1 \&$ include_nmsc $=1 \&$ include_nmsc_other=1\&type_multiple $=\% 257 \mathrm{~B} \% 2522$ inc $\% 2522 \% 253$ Atrue $\% 252 \mathrm{C}$ $\% 2522$ mort\%2522\%253Afalse $\% 252$ C\%2522prev\%2522\%253Afalse\%257D\&orientation=horizontal\&type_sort=0\&type_nb_ items $=\% 257 \mathrm{~B} \% 2522$ top $\% 2522 \% 253$ Atrue $\% 252 \mathrm{C} \% 2522$ bottom\%2522\%253Afalse\%257D\&population_group_globocan_id=

12. González CME, Céspedes QMC, González $\mathrm{Cl}$, Infante CMC, Vinent CAM. Reacciones adversas al tratamiento radiante en el adulto mayor con cáncer. MediSan [Internet]. 2015 [citado 2019 noviembre 22];19(1):18-25. Disponible en: https://www.medigraphic.com/ cgi-bin/new/resumen.cgi?IDARTICULO $=55809$

13. Mingorance JM, Arbinaga F, Márquez C), Calero BJ. Coping strategies and self-esteem in women with breast cancer. Anal Psicol [Internet]. 2019 [citado 2020 junio 4]; 35(2): 188-194. DOI: https:// doi.org/10.6o18/analesps.35.2.336941

14. Costa DT, Rodrigues MD, Cavalcanti ID, Gomes ET, Vasconcelos $\mathrm{JL}$, Gorayeb MV. Religious/spiritual coping and level of hope in patients with cancer in chemotherapy. Rev Bras Enferm. [Internet]. 2019 [citado 2020 junio 4];72(3):640-645. DOI: https://doi. org/10.1590/0034-7167-2018-0358

15. Hidalgo A, Pantoja A, Sañudo VP, Rocha BA. Coping and Quality of Life in Oncologic Patients of the Province of Nariño, Colombia. Rev Fac Med. [Internet]. 2016 [citado 2020 mayo 18];64(2):181-188. DOI: https://doi.org/10.15446/revfacmed.v64n2.52409

16. Ponciano C. Quality of life and coping in adult oncological patients of a Lima-Peru Clinic. Journal Science and Art Nursing [Internet]. 2017 [citado 2020 junio 4];2(1):52-58. DOI: https://doi.org/10.24314/ rcae.2017.v2n1.10

17. Lostaunau V, Torrejón C, Cassaretto M. Stress, Coping And Health-Related Quality Of Life In Breast Cancer Women. AP [Internet]. 2017 [citado 2020 julio 7.];31(122):75-90. DOI: https://doi. org/10.15517/ap.v311122.25345

18. Ortiz E, Méndez LP, Camargo JA, Chavarro SA, Toro GI, Vernaza MB. Relación entre las estrategias de afrontamiento, ansiedad, depresión y autoestima, en un grupo de adultos con diagnóstico de cáncer. Psychol Av Discip [Internet]. 2014 [citado 2020 mayo 18];8(1):77-83. Disponible en: http://www.scielo.org.co/scielo. php?script=sci_arttext\&pid $=$ S1900 $-23862014000100008 \& \mathrm{I}-$ $\mathrm{ng}=\mathrm{en} \& \mathrm{nrm}=\mathrm{iso} \& \mathrm{t} \operatorname{lng}=\mathrm{es}$

19. Lashbrook MP, Valery PC, Knott V, Kirshbaum MN, Bernardes CM. Coping Strategies Used by Breast, Prostate, and Colorectal Cancer Survivors. Cancer Nursing [Internet]. 2017 [citado 2020 julio 7];41(5):E23-E39. DOI: https://doi.org/10.1097/ ncc. 0000000000000528

20. Baghjari F, Esmaeilinasab M, Shahriari-Ahmadi A. Predicting Posttraumatic Growth Based on Coping Strategies in Women and Men Involving with Advanced Cancer. Int J Cancer Manag. [Internet]. 2017 [citado 2020 julio 7];10(8): e10193. DOI: https://dx.doi. org/10.5812/ijcm.10193

21. Hermosilla A, Sanhueza O. Control emocional, felicidad subjetiva y satisfacción vital relacionados al afrontamiento y adaptación en personas con cáncer avanzado. Scielo [Internet] 2015; [citado 2020 julio 7];169(6):21(1):11-21. DOI: https://doi.org/10.4067/So71795532015000100002

22. Sari D, Dewi R, Daulay W. Association Between Family Support, Coping Strategies and Anxiety in Cancer Patients Undergoing Chemotherapy at General Hospital in Medan, North Sumatera, Indonesia. Asian Pacific Journal of Cancer Prevention [Internet] 2019 [citado 2020 julio 7];20(10):3015-3019. DOI: https://doi. org/10.31557/APJCP.2019.20.10.3015

23. Viitala A, Saukkonen MRN, Lehto JT, Palonen M, Åstedt-Kurki P. The Coping and Support Needs of Incurable Cancer Patients.
Journal of Hospice \& Palliative Nursing [Internet]. 2018 [citado 2020 julio 7];20(2):187-194. DOI: https://doi.org/10.1097/ $\mathrm{NJH} .0000000000000427$

24. Pérez P, Gónzalez A, Mieles I, Uribe AF. Relación del apoyo social, las estrategias de afrontamiento y los factores clínicos y sociodemográficos en pacientes oncológicos. Pensam Psicológico [Internet]. 2017 [citado 2020 julio 7];15(2):41-54. DOI: https://doi. org/10.11144/Javerianacali.PPSl15-2.rase

25. Chavan PP, Kedia SK, Yu X. Physical and Functional Limitations in US Older Cancer Survivors. J Palliat Care Med. [Internet]. 2017 [citado 2020 julio 7];7(4):1000312. DOI: https://doi.org/10.4172/21657386.1000312

26. Breedveld JL, Bours JL, Cords CI, Ditters AM, Habraken V, Jongen WJ, et al. The impact of participation restrictions on everyday life in long-term colorectal cancer survivors in the EnCoRe study: A mixed-method study. Eur J Oncol Nurs. [Internet]. 2020 [citado 2020 julio 7]; 45:101724. DOI: https://doi.org/10.1016/j. ejon.2020.101724

27. Yoshikawa A, Saito S, Kondo M, Tsuyumu Y, Taira N, Shien T, et al. The sexual lives of breast cancer patients: Coping with changes associated with treatment. Clin Nurs Stud. [Internet]. 2017 [citado 2020 julio 7];6(1):61-75. DOI: https://doi.org/10.5430/cns.v6n1p61

28. Manne SL, Myers-Virtue S, Kashy D, Ozga M, Kissane D, Heckman C, et al. Resilience, Positive Coping, and Quality of Life Among Women Newly Diagnosed With Gynecological Cancers. Cancer Nurs. 2015 [citado 2020 julio 7];38(5):375-382. DOI: https://doi. org/10.1097/NCC.0000000000000215

29. Acinas MP. Situaciones traumáticas y resiliencia en personas con cáncer. Psiquiatría Biológica [Internet]. 2014 [citado 2020 julio 7];21(2):65-71. DOI: https://doi.org/10.1016/j.psiq.2014.05.003

30. Sajadian A, RajiLahiji M, Motaharinasab A, Kazemnejad A, Haghighat S. Breast Cancer Coping Strategies after Diagnosis: A Six-month Follow-up. Multidiscip Cancer Investig [Internet]. 2017 [citado 2020 julio 7];1(4):12-16. DOI: https://doi.org/10.21859/ mci-01042

31. Ottati F, Souza MP. Calidad de vida y estrategias de afrontamiento en el tratamiento de pacientes oncológicos. Acta Colomb Psicol [Internet]. 2014 [citado 2020 julio 7];17(2):103-111. DOI: https://doi. org/10.14718/ACP.2014.17.2.11

32. Fierro Trujillo JP, Losada YT, Puyo M, Rodriguez HD. Tipo de afrontamiento, nivel de adaptación y funcionalidad familiar en pacientes con retinopatía diabética según escala de Callista Roy [tesis]. Neiva (Colombia): Universidad Surcolombiana; 2015.

33. Zuardin, Razak A, Alimin M, Tamar M, Yani A. Coping Strategy in Differentianting Levels of Post-Traumatic Growth on Housewives Living with Breast Cancer. Int J Innov Technol Explor Eng [Internet]. 2019 [citado 2020 julio 7];8(12):2156-2159. DOI: https://doi. org/10.35940/ijitee.L2943.1081219

34. Head B, Harris L, Kayser K, Martin A, Smith L. As if the disease was not enough: coping with the financial consequences of cancer. Support Care Cancer [Internet]. 2018 [citado 2020 julio 7]; 26:975-987. DOI: https://doi.org/10.1007/s00520-017-3918-y

35. Krikorian A, Limonero JT. Factores asociados a la experiencia de sufrimiento en pacientes con cáncer avanzado. Av Psicol Latinoam [Internet]. 2015 [citado 2020 julio 7];33(3):423-438. DOI: https:// doi.org/10.12804/revistas.urosario.edu.co/apl/a.3247

36. Dunn J, Garvey G, Valery PC, Ball D, Fong KM, Vinod S, et al. Barriers to lung cancer care: health professionals' perspectives. Support Care Cancer [Internet]. 2017 [citado 2020 julio 7]; 25:497-504. DOI: https://doi.org/10.1007/so0520-016-3428-3

37. Lebert B. Die Zukunft der onkologischen Fachpflege. Forum [Internet]. 2018 [citado 2020 julio 7];33:181-185. DOI: https://doi. org/10.1007/s12312-018-0415-2 